\title{
Kevin E. Wilk, Michael M. Reinold, James R. Andrews (eds): The athlete's shoulder second edition
}

\author{
Saunders Elsevier, Philadelphia, 2009876 pp, num figs, Hardcover XXX US \$, \\ ISBN 978-0443067013
}

Pierre Kehr

Received: 15 August 2009 / Accepted: 18 August 2009 / Published online: 29 August 2009

(C) Springer-Verlag 2009

This book presents all pathologies of the shoulder in connection with the sports.

The first three parts treat anatomy, biomechanics, clinical examination and radiological and arthroscopic surgical techniques of the shoulder.

The following chapter treats various pathologies: the diagnosis, the surgical treatment, and rehabilitation. Each pathology is well described with a rich bibliography at the end of each chapter.

The last two parts of the book make it interesting.

Pathologies specific to each sport (swimming, tennis, golf...) are well described, especially the physiopathology and the programs of rehabilitation.
The part on the principles of rehabilitation is interesting very didactic and details the various techniques.

Finally a chapter shows the various rating scales.

A book extremely interesting for all the surgeons treating sportsmen.

No funds were received in support of this study.

Alain Graftiaux

P. Kehr (四)

ArgoSpine, Strasbourg, France

e-mail: kehrpier@aol.com 